\title{
Eribulin Regresses a Doxorubicin-resistant Dedifferentiated Liposarcoma in a Patient-derived Orthotopic Xenograft Mouse Model
}

\author{
KENTARO IGARASHI ${ }^{1,2,3}$, KEI KAWAGUCHI ${ }^{1,2}$, TASUKU KIYUNA ${ }^{1,2}$, KENTARO MIYAKE $^{1,2}$, \\ TAKASHI HIGUCHI ${ }^{1,2,3}$, NORIO YAMAMOTO ${ }^{3}$, KATSUHIRO HAYASHI $^{3}$, HIROAKI KIMURA $^{3}$, \\ SHINJI MIWA ${ }^{3}$, SHREE RAM SINGH ${ }^{4}$, HIROYUKI TSUCHIYA ${ }^{3}$ and ROBERT M. HOFFMAN ${ }^{1,2}$ \\ ${ }^{1}$ AntiCancer, Inc., San Diego, CA, U.S.A.; \\ ${ }^{2}$ Department of Surgery, University of California, San Diego, CA, U.S.A.; \\ ${ }^{3}$ Department of Orthopaedic Surgery, Kanazawa University, Kanazawa, Japan; \\ ${ }^{4}$ Basic Research Laboratory, National Cancer Institute, Frederick, MD, U.S.A.
}

\begin{abstract}
Background/Aim: Dedifferentiated liposarcoma (DDLPS) is recalcitrant type of sarcoma. DDLPS has a low survival rate with high recurrence and metastasis. In the present study, we evaluated the efficacy of several drugs against doxorubicin-resistant DDLPS in a patient-derived orthotopic xenograft (PDOX) model for precision oncology. To establish the PDOX model, a tumor from a patient who had recurrent high-grade DDLPS from the retroperitoneum was previously grown orthotopically in the retroperitoneum of nude mice. Materials and Methods: We randomized DDLPS PDOX models into 8 treatment groups when tumor volume became approximately $100 \mathrm{~mm}^{3}$ : control, no treatment; G2, doxorubicin (DOX); G3, pazopanib (PAZ); G4, gemcitabine (GEM) combined with docetaxel (DOC); G5, trabectedin (YON); G6, temozolomide (TEM); G7, palbociclib (PAL); G8, eribulin (ERB). Tumor length and width were measured both at the beginning and at the end of treatment. Results: At the end of treatment (day 14), all treatments significantly inhibited DDLPS PDOX tumor growth compared to the untreated control, except DOX. ERB
\end{abstract}

This article is freely accessible online.

Correspondence to: Robert M. Hoffman, Ph.D., AntiCancer, Inc., 7917 Ostrow Street, San Diego, CA 92111, U.S.A. Tel: +1 8586542555, Email: all@anticancer.com; Hiroyuki Tsuchiya, MD, $\mathrm{PhD}$, Department of Orthopaedic Surgery, Graduate School of Medicine, Kanazawa University, 13-1 Takara-machi, Kanazawa 920-8641, Japan. E-mail: tsuchi@med.kanazawa-u.ac.jp; Shree Ram Singh, Ph.D., National Cancer Institute, Frederick, MD 21702, U.S.A.e-mail: singhshr@mail.nih.gov

Key Words: Patient-derived orthotopic xenograft, PDOX, eribulin, regression, doxorubicin resistance, dedifferentiated liposarcoma. was significantly more effective and regressed tumor volume compared to other treatments on day 14 after initiation of treatment. No significant differences were found in the relative body weight on day 14 compared to day 0 in any group. Conclusion: The clinical potential of ERB against DDLPS is herein presented in a PDOX model.

Liposarcoma is a soft tissue sarcoma (STS). Among STS, dedifferentiated liposarcoma (DDLPS) has the lowest survival rate (1) with high recurrence and metastasis rates even after treatment with first-line therapies $(2,3)$. Novel more effective therapies are needed. We have previously established a patient-derived orthotopic xenograft (PDOX) nude-mouse model for all major cancers (4-15) including DDLPS (16).

Pazopanib is a tyrosine kinase inhibitor (TKI) that blocks tumor growth and inhibits angiogenesis (17). It was highly efficacious in a Phase 3 study in patients with STS (18). Gemcitabine is a cytidine analog that is extensively used in anti-cancer therapy. Gemcitabine is easily incorporated into DNA and causes cytotoxicity by inhibiting DNA replication (19-22). Docetaxel is a cytotoxic taxane that blocks mitosis $(23,24)$. The combination of gemcitabine and docetaxel has shown synergism (25) both in vitro (26) and in vivo (27). Recent studies demonstrated that the combination of gemcitabine and docetaxel was highly effective in patients with STS (28-30). Trabectedin is a synthetic, marine-derived alkylating agent derived from the Caribbean tunicate, Ecteinascidia turbinate (31). Trabectedin is active in patients with liposarcoma (32) and has multiple mechanisms of action (33). Temozolomide is a cytotoxic prodrug which exerts cytotoxicity mainly by methylating nucleotide bases (34). Temozolomide has shown clinical 

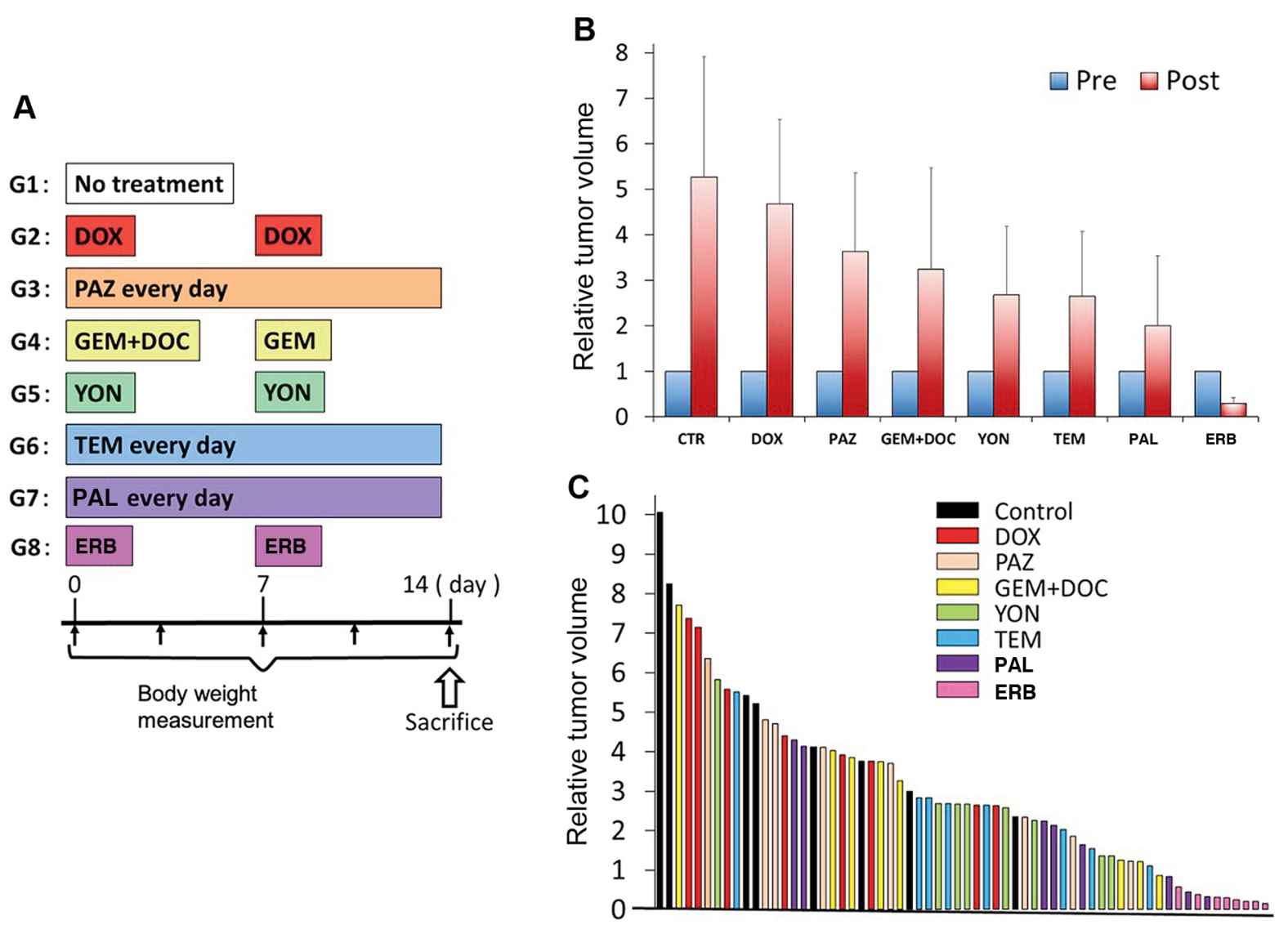

Figure 1. (A) Treatment schema for the DDLPS PDOX model. (B) Efficacy of doxorubicin (DOX), pazopanib (PAZ), gemcitabine combined with docetaxel (GEM+DOC), trabectedin (YON), temozolomide (TEM), palbociclib (PAL) and eribulin (ERB) on the DDLPS PDOX model. Tumor volume was measured pre-and post-treatment. $N=8$ mice/group. (C) Relative tumor volume for each mouse is presented in a waterfall plot.

activity against high-grade brain cancer (35), melanoma (36), and pediatric rhabdomyosarcomas (37-38). A Phase II clinical trial of temozolomide on advanced STS showed an increase in progression-free survival (39).

Cyclin-dependent kinase 4 (CDK4), is amplified in more than $90 \%$ of well-differentiated liposarcomas (WDLS)/ dedifferentiated liposarcomas (DDLS) (40-42). It has been demonstrated that inhibiting the expression of CDK4 with short hairpin RNA (shRNA) inhibits growth of STS cells in vitro (43).

Eribulin, synthesized from a marine sponge Halichondria okadai $(44,45)$, is a non-taxane microtubule-dynamics inhibitor $(46,47)$. Eribulin has been approved by the Food and Drug Administration (FDA) for aggressive breast cancer patients (48). In the United States, Eribulin has been used for the treatment of patients with inoperable or metastatic liposarcoma since 2016 (49).

The present report demonstrates that a DDLPS PDOX model identified eribulin as a highly effective drug that regresses tumor volume indicating its clinical potential.

\section{Materials and Methods}

Animal care. Male athymic nu/nu nude mice (AntiCancer Inc., San Diego, CA, USA), 4-6 weeks old, were used in the present study. Mouse studies were conducted with an AntiCancer Inc. Institutional Animal Care and Use Committee (IACUC)-protocol specifically approved for this study and in accordance with the principles and procedures outlined in the National Institutes of Health (NIH) Guide for the Care and Use of Animals under Assurance Number A38731 (16). To minimize suffering of animals during surgery, anesthesia and analgesics were provided (16).

Patient-derived tumor. A 69-year-old male patient with DDLPS of right retroperitoneum underwent radical resection with en bloc right nephrectomy (16). Two years after surgery, local recurrence resulted (16). The patient previously underwent surgical resection at the Department of Surgery, University of California, Los Angeles, USA (UCLA) (16). Written informed consent was obtained from the patient as part of a UCLA Institutional Review Board approval protocol (IRB \#10-001857) (16).

Establishment of DDLPS PDOX model. A fresh specimen of the tumor of the patient was previously obtained and transported 

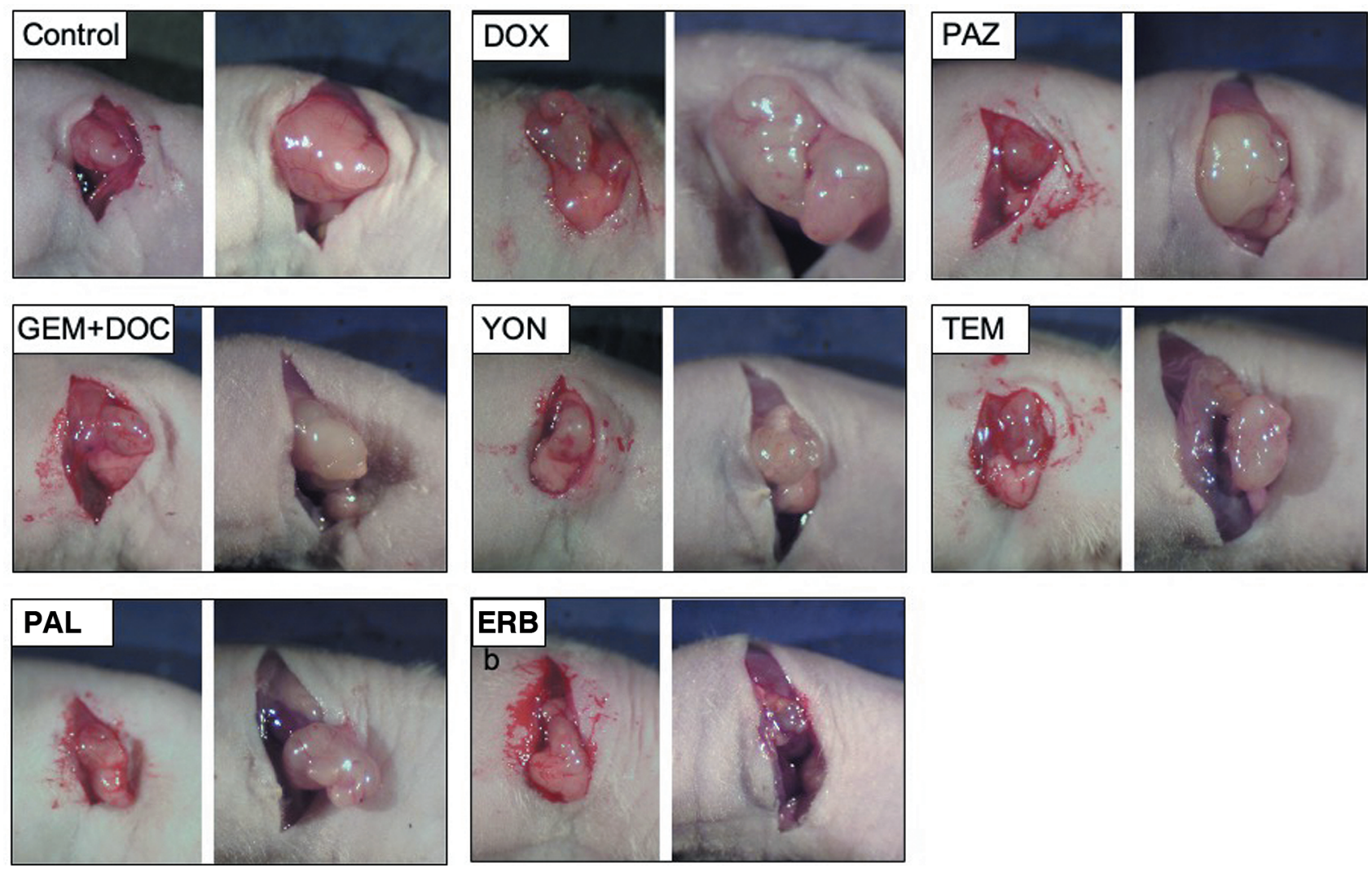

Figure 2. Representative images of DDLPS PDOX models, pre-(left panels) and post-(right panels) treatment.

immediately to the laboratory at AntiCancer, Inc., on wet ice (16) The detailed procedure of cutting samples into small fragments and their initial implantation subcutaneously in nude mice, to subsequently establish PDOX models and wound closure has been described in our previous publication (16).

Treatment protocols for the DDLPS PDOX model. PDOX mouse models were randomly divided into 8 groups: G1, control no treatment; G2, doxorubicin (DOX) [3 mg/kg, intraperitoneal (i.p.) injection, weekly, for 2 weeks]; G3, pazopanib (PAZ) [100 mg/kg, p.o., daily, for 2 weeks]; G4, gemcitabine (GEM) $(100 \mathrm{mg} / \mathrm{kg}$, i.p., weekly, for 2 weeks) combined with docetaxel (DOC) $(20 \mathrm{mg} / \mathrm{kg}$, i.p., once); G5, trabectedin (YON) $[0.15 \mathrm{mg} / \mathrm{kg}$, intravenous (i.v.) injection, weekly, for 2 weeks]; G6, temozolomide (TEM) (25 $\mathrm{mg} / \mathrm{kg}$, p.o., daily, for 2 weeks); G7, palbociclib (PAL) $(100 \mathrm{mg} / \mathrm{kg}$, p.o., daily, for 2 weeks); G8, eribulin (ERB) $(1.5 \mathrm{mg} / \mathrm{kg}, i . v$. , weekly, for 2 weeks) (Figure 1A). Each treatment group contained 8 mice. Tumor length and width were measured both before and after treatment. Tumor volume was calculated based on our previous studies (16). The tumor volume ratio is defined at the tumor volume at a post-treatment point relative to pre-treatment tumor volume (50).

Histological examination. Detailed protocols to fix the fresh tumor samples, embedding in paraffin, sectioning and staining were described previously (16). Hematoxylin and eosin (H\&E) staining was performed according to a standard protocol (16). Histological examination was performed with a BHS system microscope and images were acquired with INFINITY ANALYZE software (Lumenera Corporation, Ottawa, Canada).

Statistical analysis. All statistical analyses were performed as previously described (50). The Student's $t$-test was used to determine the significant differences for continuous variables. Data are presented as mean \pm standard deviation $(\mathrm{SD})$. A probability value $p \leq 0.05$ was considered a statistically-significant difference.

\section{Results}

Drug efficacy. At the end of treatment (Day 14), all treatments significantly inhibited DDLPS tumor growth compared to the untreated control except DOX: (DOX: $p=0.61$; PAZ: $p=0.17$; GEM+DOC: $p=0.11$; YON $p=0.04$; TEM: $p=0.04$; PAL: $p=0.01$; ERB: $p=0.001)$. However, ERB was significantly more effective compared to DOX $(p=0.001), \operatorname{PAZ}(p=0.001), \mathrm{GEM}+\mathrm{DOC}(p=0.001), \mathrm{YON}$ $(p=0.001)$, TEM $(p=0.001)$ and PAL $(p=0.01)$. In addition, ERB significantly regressed tumor volume by the end of treatment (day 14) compared with day $0(p=0.001)$ (Figures 1 and 2). 


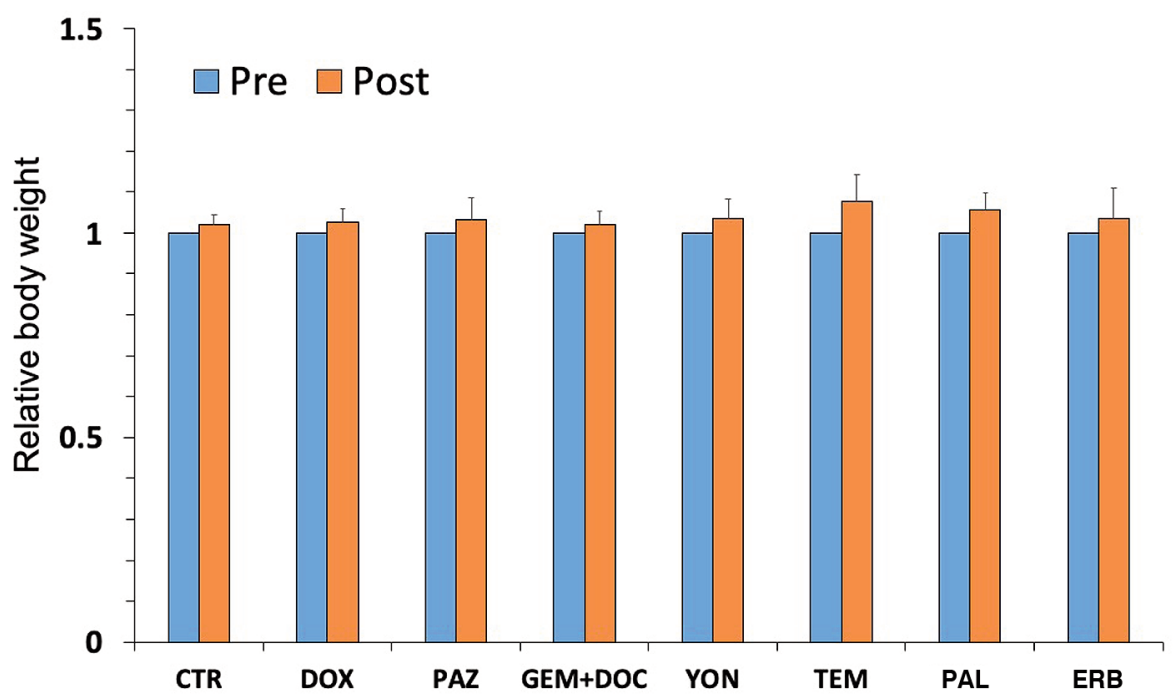

Figure 3. Body weight of (DOX); pazopanib (PAZ); gemcitabine combined with docetaxel (GEM+DOC); trabectedin (YON); temozolomide (TEM); palbociclib (PAL); and eribulin (ERB). Bar graph shows body weight in each group before (day 0) and after treatment (day14). N=8 mice/group.
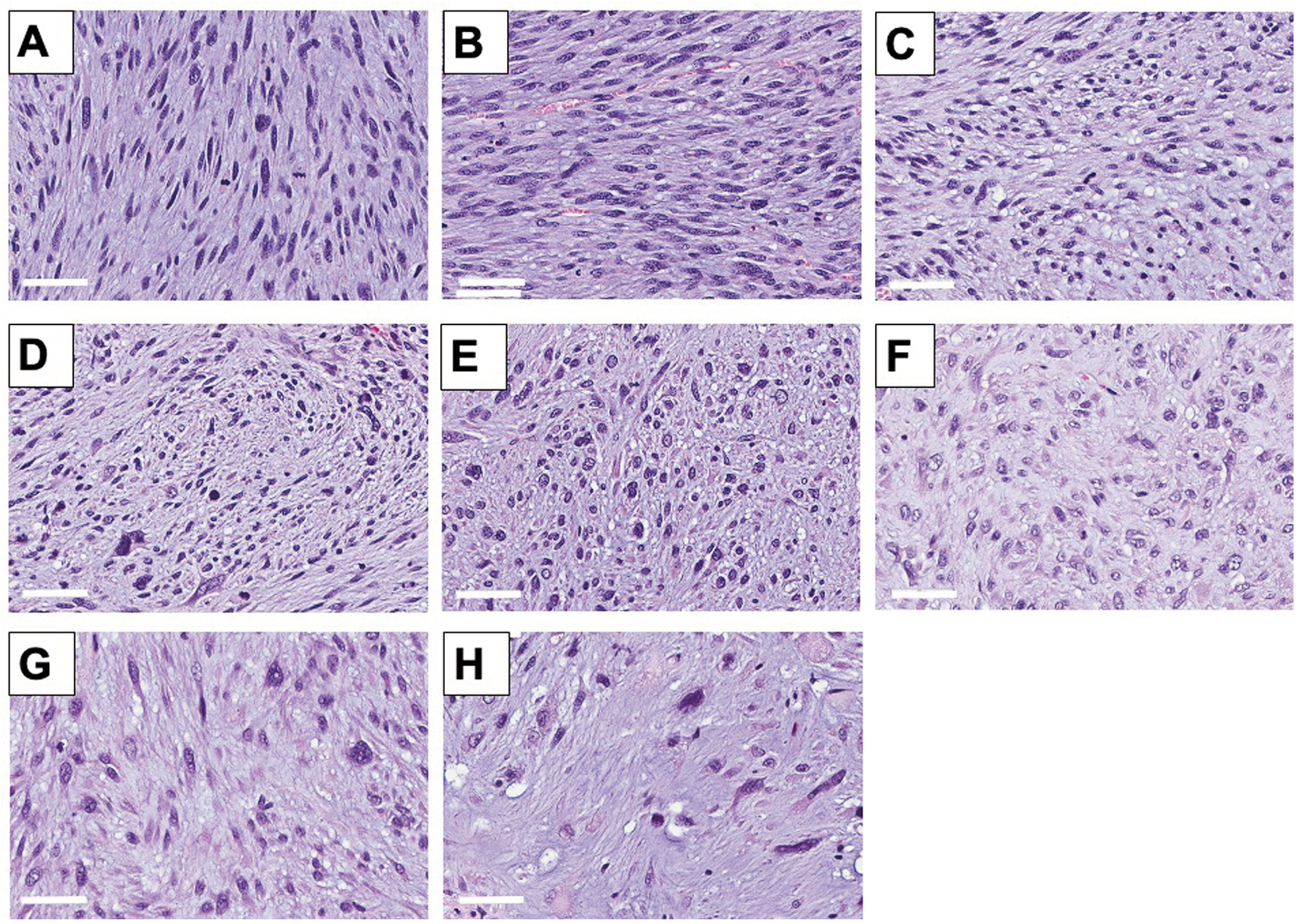

Figure 4. Tumor histology. H\&E-stained sections of the untreated PDOX tumor (A); PDOX tumor treated with doxorubicin (DOX) (B); PDOX tumor treated with pazopanib $(P A Z)(C)$; PDOX tumor treated with gemcitabine combined with docetaxel $(G E M+D O C)(D)$; PDOX tumor treated with trabectedin (YON) (E); PDOX tumor treated with temozolomide (TEM) (F); PDOX tumor treated with palbociclib $(P A L)(G)$; and PDOX tumor treated with eribulin $(E R B)(H)$. White scale bars: $50 \mu \mathrm{m}$. 
Body weight. No significant difference was observed in the relative body weight on day 14 compared to day 0 in any treatment group (Figure 3).

Histology. High-power photomicrographs of the untreated control PDOX tumor show spindle cells with hyperchromatic and enlarged nuclei. Mitotic figures and atypical cells are present (Figure 4A). Tumors treated with DOX and PAZ had viable cells with no obvious necrosis or inflammatory changes (Figure 4B and C). Tumors treated with GEM+DOC and YON show changes in cancer-cell shapes and few necrotic cancer cells (Figure 4D and E). Tumors treated with TEM and PAL show changes in cancercell shapes, few necrotic cancer cells and also fibrotic areas (Figure 4F and G). In contrast, tumors treated with ERB show decreased tumor cellularity, necrotic cancer cells and tissue fibrosis (Figure $4 \mathrm{H}$ ).

\section{Discussion}

DDLPS is a recalcitrant sarcoma with the lowest survival rate among liposarcoma. DDLPS frequently recurs or metastasizes after first therapy because no current curative options are available $(1,2)$. Therefore, transformative, personalized and effective therapy is urgently needed for DDLPS patients.

PDOX models have provided clinically-relevant individualized mouse models of cancer since PDOX models recapitulate clinical behavior, and mimic tumor-specific drug-sensitivity (51). PDOX models of sarcoma behave very similarly to patient sarcoma in terms of recurrence after surgery (15), and metastasis (52) and invasiveness to surrounding tissue $(15,53)$.

Using PDOX models, multiple therapeutic agents can be tested (53-60), including targeted therapy in a preclinical model (61-66).

In the present study, ERB was found to regress the DDLPS PDOX tumor. The present study, using PDOX models, provides DDLPS patients with specific and personalized treatment options. Future studies will label the DDLPS PDOX tumors with fluorescent proteins by growing them in transgenic nude mice expressing fluorescent proteins, whereby the PDOX tumor acquires fluorescent stromal cells. Such labeled tumors will be used to detect metastasis in non-colored mice $(52,67)$. Thus far, all sarcoma PDOX models have correlated with drug resistance in the patient (68).

\section{Conflicts of Interest}

KI, KK, TK, KM, TH, NY, KH, HK, SM and RMH are or were unsalaried members of AntiCancer Inc., which uses PDOX models for contract research. There are no other competing financial interests.

\section{Authors' Contributions}

Conception and design: KI and RMH. Acquisition of data: KI, KK, TK, KM and TH. Analysis and interpretation of data: KI, KK, TK, KM, TH, NY, KH, HK, SM, SRS, HT and RMH. Writing, review, and/or revision of the manuscript: KI, RMH and SRS.

\section{Acknowledgements}

This paper is dedicated to the memory of AR Moossa, MD, Sun Lee, MD, Professor Li Jiaxi, and Masaki Kitajima, MD.

\section{References}

1 Jones RL, Fisher C, Al-Muderis O and Judson IR: Differential sensitivity of liposarcoma subtypes to chemotherapy. Eur J Cancer 41: 2853-2860, 2005. PMID: 16289617. DOI: 10.1016/j.ejca.2005.07.023

2 Crago AM and Singer S: Clinical and molecular approaches to well differentiated and dedifferentiated liposarcoma. Curr Opin Oncol 23: 373-378, 2011. PMID: 21552124. DOI: 10.1097/CCO.0b013e32834796e6

3 Lorigan P, Verweij J, Papai Z, Rodenhuis S, Le Cesne A, Leahy MG, Radford JA, Van Glabbeke MM, Kirkpatrick A, Hogendoorn PCW and Blay J-Y: Phase III Trial of two investigational schedules of ifosfamide compared with standard-dose doxorubicin in advanced or metastatic soft tissue sarcoma: A European organisation for research and treatment of cancer soft tissue and bone sarcoma Group Study. J Clin Oncol 25: 3144-3150, 2007. PMID: 17634494. DOI: 10.1200/JCO.2006.09.7717

4 Fu X, Guadagni F and Hoffman RM: A metastatic nude-mouse model of human pancreatic cancer constructed orthotopically with histologically intact patient specimens. Proc Natl Acad Sci 89: 5645-5649, 1992. PMID: 1608975. DOI: 10.1073/pnas.89.12.5645

5 Hiroshima Y, Maawy A, Zhang Y, Murakami T, Momiyama M, Mori R, Matsuyama R, Katz MHG, Fleming JB, Chishima T, Tanaka K, Ichikawa Y, Endo I, Hoffman RM and Bouvet M: Metastatic recurrence in a pancreatic cancer patient derived orthotopic xenograft (PDOX) nude mouse model is inhibited by neoadjuvant chemotherapy in combination with fluorescenceguided surgery with an anti-CA 19-9-conjugated fluorophore. PLoS One 9:e114310, 2014. PMID: 25463150. DOI: 10.1371/journal.pone.0114310

6 Fu X, Le P and Hoffman RM: A metastatic orthotopic transplant nude-mouse model of human patient breast cancer. Anticancer Res 13: 901-904, 1993. PMID: 8352558.

7 Fu X and Hoffman RM: Human ovarian carcinoma metastatic models constructed in nude mice by orthotopic transplantation of histologically-intact patient specimens. Anticancer Res 13: 283-286, 1993. PMID: 8517640.

8 Wang X, Fu X and Hoffman RM: A new patient-like metastatic model of human lung cancer constructed orthotopically with intact tissue via thoracotomy in immunodeficient mice. Int J Cancer 51: 992-995, 1992. PMID: 1639545. DOI: 10.1002/ijc.2910510626

9 Hiroshima Y, Zhang Y, Zhang N, Maawy A, Mii S, Yamamoto M, Uehara F, Miwa S, Yano S, Murakami T, Momiyama M, Chishima T, Tanaka K, Ichikawa Y, Bouvet M, Murata T, Endo I and Hoffman RM: Establishment of a patient-derived orthotopic xenograft (PDOX) model of HER-2-positive cervical cancer 
expressing the clinical metastatic pattern. PLoS One 10: e0117417, 2015. PMID: 25689852. DOI: 10.1371/journal.pone.0117417

$10 \mathrm{Fu}$ X, Besterman JM, Monosov A and Hoffman RM: Models of human metastatic colon cancer in nude mice orthotopically constructed by using histologically intact patient specimens. Proc Natl Acad Sci USA 88: 9345-9349, 1991. PMID: 1924398. DOI: 10.1073/pnas.88.20.9345

11 Metildi CA, Kaushal S, Luiken GA, Talamini MA, Hoffman RM and Bouvet $\mathrm{M}$ : Fluorescently labeled chimeric anti-CEA antibody improves detection and resection of human colon cancer in a patient-derived orthotopic xenograft (PDOX) nude mouse model. J Surg Oncol 109: 451-458, 2014. PMID: 24249594. DOI: $10.1002 /$ jso.23507

12 Furukawa T, Kubota T, Watanabe M, Kitajima M, Hoffman RM.: Orthotopic transplantation of histologically intact clinical specimens of stomach cancer to nude mice: Correlation of metastatic sites in mouse and individual patient donors. Int J Cancer 53: 608-612, 1993. PMID: 8436434. DOI: 10.1002/ijc.2910530414

13 Murakami T, DeLong J, Eilber FC, Zhao M, Zhang Y, Zhang N, Singh A, Russell T, Deng S, Reynoso J, Quan C, Hiroshima Y, Matsuyama R, Chishima T, Tanaka K, Bouvet M, Chawla S, Endo I and Hoffman RM: Tumor-targeting Salmonella typhimurium A1-R in combination with doxorubicin eradicate soft tissue sarcoma in a patient-derived orthotopic xenograft (PDOX) model. Oncotarget 7: 12783-12790, 2016. PMID: 26859573. DOI: 10.18632 /oncotarget.7226

14 Kiyuna T, Murakami T, Tome Y, Kawaguchi K, Igarashi K, Zhang Y, Zhao M, Li Y, Bouvet M, Kanaya F, Singh A, Dry S, Eilber FC and Hoffman RM: High efficacy of tumor-targeting Salmonella typhimurium A1-R on a doxorubicin- and dactolisib-resistant follicular dendritic-cell sarcoma in a patient-derived orthotopic xenograft PDOX nude mouse model. Oncotarget 7: 33046-33054, 2016. PMID: 27105519. DOI: 10.18632/oncotarget.8848

15 Igarashi K, Kawaguchi K, Kiyuna T, Murakami T, Miwa S, Nelson SD, Dry SM, Li Y, Singh A, Kimura H, Hayashi K, Yamamoto N, Tsuchiya H, Eilber FC and Hoffman RM: Patientderived orthotopic xenograft (PDOX) mouse model of adult rhabdomyosarcoma invades and recurs after resection in contrast to the subcutaneous ectopic model. Cell Cycle 16: 91-94, 2017. PMID: 27830986. DOI: 10.1080/15384101.2016.1252885

16 Igarashi K, Kawaguchi K, Kiyuna T, Miyake K, Miyaki M, Yamamoto N, Hayashi K, Kimura H, Miwa S, Higuchi T, Singh AS, Chmielowski B, Nelson SD, Russell TA, Eckardt MA, Dry SM, Li Y, Singh SR, Chawla SP, Eilber FC, Tsuchiya H and Hoffman RM: Metabolic targeting with recombinant methioninase combined with palbociclib regresses a doxorubicin-resistant dedifferentiated liposarcoma. Biochem Biophys Res Commun 506: 912-917, 2018. PMID: 30392912. DOI: $10.1016 /$ j.bbrc.2018.10.119

17 Schöffski P: Pazopanib in the treatment of soft tissue sarcoma. Expert Rev Anticancer Ther 12: 711-723, 2012. PMID: 22716487. DOI: 10.1586/era.12.41

18 Van Der Graaf WTA, Blay JY, Chawla SP, Kim DW, Bui-Nguyen B, Casali PG, Schöffski P, Aglietta M, Staddon AP, Beppu Y, Le Cesne A, Gelderblom H, Judson IR, Araki N, Ouali M, Marreaud S, Hodge R, Dewji MR, Coens C, Demetri GD, Fletcher CD, Dei Tos AP and Hohenberger P: Pazopanib for metastatic soft-tissue sarcoma (PALETTE): A randomised, double-blind, placebocontrolled phase 3 trial. Lancet 79: 1879-1886, 2012. PMID: 22595799. DOI: $10.1016 / \mathrm{S} 0140-6736(12) 60651-5$
19 Hertel LW and Lawrence TS: Metabolism of 2',2'-Difluoro-2'Deoxycytidine and radiation sensitization of human colon carcinoma cells. Cancer Res 54: 3218-3223, 1994. PMID: 8205542.

20 Iwasaki H, Huang P, Keating MJ and Plunkett W: Differential incorporation of ara-C, gemcitabine, and fludarabine into replicating and repairing DNA in proliferating human leukemia cells. Blood 90: 270-278, 1997. PMID: 9207462.

21 Huang P, Chubb S, Hertel LW, Grindey GB and Plunkett W: Action of 2',2'-difluorodeoxycytidine on DNA synthesis. Cancer Res 51: 6110-6117, 1991. PMID: 1718594.

22 Ross DD and Cuddy DP: Molecular effects of 2,2difluorodeoxycytidine (gemcitabine) on DNA replication in intact HL-60 cells. Biochem Pharmacol 48: 1619-1630, 1994. PMID: 7980627. DOI: 10.1016/0006-2952(94)90207-0

23 Schiff PB, Fant J and Horwitz SB: Promotion of microtubule assembly in vitro by taxol. Nature 277: 665-667, 1979. PMID: 423966. DOI: $10.1038 / 277665 \mathrm{a} 0$

24 Rowinsky EK, Onetto N, Canetta RM and Arbuck SG: Taxol: The first of the taxanes, an important new class of antitumor agents. Semin Oncol 19: 646-662, 1992. PMID: 1361079.

25 Smorenburg CH, Sparreboom A, Bontenbal M and Verweij J: Combination chemotherapy of the taxanes and antimetabolites: Its use and limitations. Eur J Cancer 37: 2310-2323, 2001. PMID: 11720823. DOI: 10.1016/s0959-8049(01)00309-4

26 Leu KM, Ostruszka LJ, Shewach D, Zalupski M, Sondak V, Sybil Biertnann J, Lee JSJ, Couwlier C, Palazzolo K and Baker LH: Laboratory and clinical evidence of synergistic cytotoxicity of sequential treament with gemcitabine followed by docetaxel in the treatment of sarcoma. J Clin Oncol 22: 1706-1712, 2004. PMID: 15117993. DOI: 10.1200/JCO.2004.08.043

27 Alexopoulos A, Tryfonopoulos D, Karamouzis M V., Gerasimidis G, Karydas I, Kandilis K, Stavrakakis J, Stavrinides $\mathrm{H}$, Georganta C, Ardavanis A and Rigatos G: Evidence for in vivo synergism between docetaxel and gemcitabine in patients with metastatic breast cancer. Ann Oncol 15: 95-99, 2004. PMID: 14679126. DOI: 10.1093/annonc/mdh028

28 Hensley ML, Maki R, Venkatraman E, Geller G, Lovegren M, Aghajanian C, Sabbatini P, Tong W, Barakat R and Spriggs DR: Gemcitabine and docetaxel in patients with unresectable leiomyosarcoma: Results of a phase II trial. J Clin Oncol 20: 28242831, 2002. PMID: 12065559. DOI: 10.1200/JCO.2002.11.050

29 Maki RG, Wathen JK, Patel SR, Priebat DA, Okuno SH, Samuels B, Fanucchi M, Harmon DC, Schuetze SM, Reinke D, Thall PF, Benjamin RS, Baker LH and Hensley ML: Randomized Phase II study of gemcitabine and docetaxel compared with gemcitabine alone in patients with metastatic soft tissue sarcomas: Results of sarcoma alliance for research through collaboration study 002. J Clin Oncol 25: 2755-2763, 2007. PMID: 17602081. DOI: 10.1200/JCO.2006.10.4117

30 Bay JO, Ray-Coquard I, Fayette J, Leyvraz S, Cherix S, Piperno-Neumann S, Chevreau C, Isambert N, Brain E, Emile G, Le Cesne A, Cioffi A, Kwiatkowski F, Coindre JM, Bui NB, Peyrade F and Blay JY: Docetaxel and gemcitabine combination in 133 advanced soft-tissue sarcomas: A retrospective analysis. Int J Cancer 119: 706-711, 2006. PMID: 16496406. DOI: $10.1002 /$ ijc .21867

31 Cuevas C and Francesch A: Development of Yondelis ${ }^{\circledR}$ (trabectedin, ET-743). A semisynthetic process solves the supply problem. Nat Prod Rep 26: 322-337, 2009. PMID: 19240944. DOI: $10.1039 / \mathrm{b} 808331 \mathrm{~m}$ 
32 Le Cesne A, Ray-Coquard I, Duffaud F, Chevreau C, Penel N, Bui Nguyen B, Piperno-Neumann S, Delcambre C, Rios M, Chaigneau L, Le Maignan C, Guillemet C, Bertucci F, Bompas E, Linassier C, Olivier T, Kurtz JE, Even C, Cousin P and Yves Blay J: Trabectedin in patients with advanced soft tissue sarcoma: A retrospective national analysis of the French Sarcoma Group. Eur J Cancer 51: 742-750, 2015. PMID: 25727882. DOI: $10.1016 /$ j.ejca.2015.01.006

33 Germano G, Frapolli R, Belgiovine C, Anselmo A, Pesce S, Liguori M, Erba E, Uboldi S, Zucchetti M, Pasqualini F, Nebuloni M, van Rooijen N, Mortarini R, Beltrame L, Marchini S, Fuso Nerini I, Sanfilippo R, Casali PG, Pilotti S, Galmarini CM, Anichini A, Mantovani A, D'Incalci M and Allavena P: Role of macrophage targeting in the antitumor activity of trabectedin. Cancer Cell 23: 249-262, 2013. PMID: 23410977. DOI: $10.1016 /$ j.ccr.2013.01.008

34 Tisdale MJ: Antitumour imidazotetrazines - XV. Biochem Pharmacol 36: 457-462, 1987. DOI: 10.1016/0006-2952(87)90351-0

35 Yung WKA, Prados MD, Yaya-Tur R, Rosenfeld SS, Brada M, Friedman HS, Albright R, Olson J, Chang SM, O’Neill AM, Friedman AH, Bruner J, Yue N, Dugan M, Zaknoen S and Levin VA: Multicenter phase II trial of temozolomide in patients with anaplastic astrocytoma or anaplastic oligoastrocytoma at first relapse. J Clin Oncol 17: 2762-2762, 1999. PMID: 10561351. DOI: $10.1200 / J C O .1999 .17 .9 .2762$

36 Bleehen NM, Newlands ES, Lee SM, Thatcher N, Selby P, Calvert AH, Rustin GJS, Brampton M and Stevens MFG: Cancer Research Campaign phase II trial of temozolomide in metastatic melanoma. J Clin Oncol 13: 910-913, 1995. PMID: 7707118. DOI: $10.1200 / J C O .1995 .13 .4 .910$

37 Middlemas DS, Stewart CF, Kirstein MN, Poquette C, Friedman HS, Houghton PJ and Brent TP: Biochemical correlates of temozolomide sensitivity in pediatric solid tumor xenograft models. Clin Cancer Res 6: 998-1007, 2000. PMID: 10741727.

38 Houghton PJ, Stewart CF, Cheshire PJ, Richmond LB, Kirstein MN, Poquette CA, Tan M, Friedman HS and Brent TP: Antitumor activity of temozolomide combined with irinotecan is partly independent of O6-methylguanine-DNA methyltransferase and mismatch repair phenotypes in xenograft models. Clin Cancer Res 6: 4110-4118, 2000. PMID: 11051264.

39 Garcia Del Muro X, Lopez-Pousa A, Martin J, Buesa JM, Martinez-Trufero J, Casado A, Poveda A, Cruz J, Bover I and Maurel J: A phase II trial of temozolomide as a 6-week, continuous, oral schedule in patients with advanced soft tissue sarcoma: A study by the spanish group for research on sarcomas. Cancer 104: 1706-1712, 2005. PMID: 16134177. DOI: $10.1002 / \mathrm{cncr} .21384$

40 Binh MBN, Sastre-Garau X, Guillou L, Pinieux G de, Terrier P, Lagace R, Aurias A, Hostein I and Coindre JM: MDM2 and CDK4 immunostainings are useful adjuncts in diagnosing welldifferentiated and dedifferentiated liposarcoma subtypes. Am J Surg Pathol 29: 1340-1347, 2005. PMID: 16160477. DOI: 10.1097/01.pas.0000170343.09562.39

41 Sirvent N, Coindre J-M, Maire G, Hostein I, Keslair F, Guillou L, Ranchere-Vince D, Terrier P and Pedeutour F: Detection of MDM2-CDK4 amplification by fluorescence in situ hybridization in 200 paraffin-embedded tumor samples: Utility in diagnosing adipocytic lesions and comparison with immunohistochemistry and real-time PCR. Am J Surg Pathol 31: 1476-1489, 2007. PMID: 17895748. DOI: 10.1097/PAS.0b013e3180581fff
42 Tap WD, Eilber FC, Ginther C, Dry SM, Reese N, Barzan-Smith K, Chen H-W, Wu H, Eilber FR, Slamon DJ and Anderson L: Evaluation of well-differentiated/de-differentiated liposarcomas by high-resolution oligonucleotide array-based comparative genomic hybridization. Genes Chromosom Cancer 50: 95-112, 2011. PMID: 21117066. DOI: 10.1002/gcc.20835

43 Barretina J, Taylor BS, Banerji S, Ramos AH, Lagos-Quintana M, DeCarolis PL, Shah K, Socci ND, Weir BA, Ho A, Chiang DY, Reva B, Mermel CH, Getz G, Antipin Y, Beroukhim R, Major JE, Hatton C, Nicoletti R, Hanna M, Sharpe T, Fennell TJ, Cibulskis K, Onofrio RC, Saito T, Shukla N, Lau C, Nelander S, Silver SJ, Sougnez C, Viale A, Winckler W, Maki RG, Garraway LA, Lash A, Greulich H, Root DE, Sellers WR, Schwartz GK, Antonescu CR, Lander ES, Varmus HE, Ladanyi M, Sander C, Meyerson M and Singer S: Subtype-specific genomic alterations define new targets for soft-tissue sarcoma therapy. Nat Genet 42: 715-721, 2010. PMID: 20601955. DOI: 10.1038/ng.619

44 Bai R, Paull KD, Herald CL, Malspeis L, Pettit GR and Hamel E: Halichondrin $\mathrm{B}$ and homohalichondrin $\mathrm{B}$, marine natural products binding in the vinca domain of tubulin: Discovery of tubulinbased mechanism of action by analysis of differential cytotoxicity data. J Biol Chem 266: 15882-15889, 1991. PMID: 1874739.

45 Towle MJ, Salvato KA, Budrow J, Wels BF, Kuznetsov G, Aalfs KK, Welsh S, Zheng W, Seletsky BM, Palme MH, Habgood GJ, Singer LA, Dipietro L V., Wang Y, Chen JJ, Quincy DA, Davis A, Yoshimatsu K, Kishi Y, Yu MJ and Littlefield BA: In vitro and in vivo anticancer activities of synthetic macrocyclic ketone analogues of halichondrin B. Cancer Res 61: 1013-1021, 2001. PMID: 11221827.

46 Jordan MA and Wilson L: Microtubules as a target for anticancer drugs. Nat Rev Cancer 4: 253-265, 2004. PMID: 15057285. DOI: $10.1038 / \mathrm{nrc} 1317$

47 Okouneva T, Azarenko O, Wilson L, Littlefield BA and Jordan MA: Inhibition of centromere dynamics by eribulin (E7389) during mitotic metaphase. Mol Cancer Ther 7: 2003-2011, 2008. PMID: 18645010. DOI: 10.1158/1535-7163.MCT-08-0095

48 Cigler T and Vahdat LT: Eribulin mesylate for the treatment of breast cancer. Expert Opin Pharmacother 11: 1587-1593, 2010. PMID: 20450446. DOI: 10.1517/14656566.2010.486790

49 Emambux $\mathrm{S}$ and Italiano A: Clinical efficacy of eribulin mesylate for the treatment of metastatic soft tissue sarcoma. Expert Opin Pharmacother 18: 819-824, 2017. PMID: 28468516. DOI: $10.1080 / 14656566.2017 .1326908$

50 Kawaguchi K, Igarashi K, Murakami T, Chmielowski B, Kiyuna T, Zhao M, Zhang Y, Singh A, Unno M, Nelson SD, Russell TA, Dry SM, Li Y, Eilber FC and Hoffman RM: Tumor-targeting Salmonella typhimurium A1-R combined with temozolomide regresses malignant melanoma with a BRAF-V600E mutation in a patient-derived orthotopic xenograft (PDOX) model. Oncotarget 7: 85929-85936, 2016. PMID: 27835903. DOI: 10.18632/oncotarget.13231

51 Hiroshima Y, Maawy A, Zhang Y, Zhang N, Murakami T, Chishima T, Tanaka K, Ichikawa Y, Bouvet M, Endo I and Hoffman RM: Patient-derived mouse models of cancer need to be orthotopic in order to evaluate targeted anti-metastatic therapy. Oncotarget 7: 71696-71702, 2016. PMID: 27765934. DOI: 10.18632 /oncotarget.12322

52 Oshiro H, Kiyuna T, Tome Y, Miyake K, Kawaguchi K, Higuchi T, Miyake M, Zhang Z, Razmjooei S, Barangi M, Wangsiricharoen 
S, Nelson SD, Li Y, Bouvet M, Singh SR, Kanaya F and Hoffman RM: Detection of metastasis in a patient-derived orthotopic xenograft (PDOX) model of undifferentiated pleomorphic sarcoma with red fluorescent protein. Anticancer Res 39: 81-85, 2019. PMID: 30591443. DOI: 10.21873/anticanres.13082

53 Igarashi K, Murakami T, Kawaguchi K, Kiyuna T, Miyake K, Zhang Y, Nelson SD, Dry SM, Li Y, Yanagawa J, Russell TA, Singh AS, Tsuchiya H, Elliott I, Eilber FC and Hoffman RM: A patient-derived orthotopic xenograft (PDOX) mouse model of a cisplatinum-resistant osteosarcoma lung metastasis that was sensitive to temozolomide and trabectedin: Implications for precision oncology. Oncotarget 8: 62111-62119, 2017. PMID: 28977930. DOI: 10.18632/oncotarget.19095

54 Miyake K, Murakami T, Kiyuna T, Igarashi K, Kawaguchi K, Miyake M, Li Y, Nelson SD, Dry SM, Bouvet M, Elliott IA, Russell TA, Singh AS, Eckardt MA, Hiroshima Y, Momiyama M, Matsuyama R, Chishima T, Endo I, Eilber FC and Hoffman RM: The combination of temozolomide-irinotecan regresses a doxorubicin-resistant patient-derived orthotopic xenograft (PDOX) nude-mouse model of recurrent Ewing's sarcoma with a FUS-ERG fusion and CDKN2A deletion: Direction for thirdline patient therapy. Oncotarget 8: 103129-103136, 2017. PMID: 29262551. DOI: $10.18632 /$ oncotarget.20789

55 Kawaguchi K, Igarashi K, Miyake K, Kiyuna T, Miyake M, Singh AS, Chmielowski B, Nelson SD, Russell TA, Dry SM, Li Y, Unno M, Singh SR, Eilber FC and Hoffman RM: Patterns of sensitivity to a panel of drugs are highly individualised for undifferentiated/unclassified soft tissue sarcoma (USTS) in patient-derived orthotopic xenograft (PDOX) nude-mouse models. J Drug Target 27: 211-216, 2019. PMID: 30024282. DOI: 10.1080/1061186X.2018.1499748

56 Igarashi K, Kawaguchi K, Kiyuna T, Murakami T, Miwa S, Nelson SD, Dry SM, Li Y, Singh AS, Kimura H, Hayashi K, Yamamoto N, Tsuchiya H, Eilber FC and Hoffman RM: Temozolomide combined with irinotecan caused regression in an adult pleomorphic rhabdomyosarcoma patient-derived orthotopic xenograft (PDOX) nude-mouse model. Oncotarget 8: 7587475888, 2017. PMID: 29100276. DOI: 10.18632/oncotarget.16548

57 Igarashi K, Kawaguchi K, Kiyuna T, Miyake K, Miyake M, Li Y, Nelson SD, Dry SM, Singh AS, Elliott IA, Russell TA, Eckardt MA, Yamamoto N, Hayashi K, Kimura H, Miwa S, Tsuchiya H, Eilber FC and Hoffman RM: Temozolomide combined with irinotecan regresses a cisplatinumresistant relapsed osteosarcoma in a patient-derived orthotopic xenograft (PDOX) precision-oncology mouse model. Oncotarget 9: 77747781, 2018. PMID: 29487690. DOI: 10.18632/oncotarget.22892

58 Igarashi K, Kawaguchi K, Kiyuna T, Miyake K, Miyake M, Li Y, Nelson SD, Dry SM, Singh AS, Elliott IA, Russell TA, Eckardt MA, Yamamoto N, Hayashi K, Kimura H, Miwa S, Tsuchiya H, Eilber FC and Hoffman RM: Temozolomide regresses a doxorubicin-resistant undifferentiated spindle-cell sarcoma patient-derived orthotopic xenograft (PDOX): precision-oncology nude-mouse model matching the patient with effective therapy. J Cell Biochem 119: 6598-6603, 2018. PMID: 29737543. DOI: $10.1002 /$ jcb.26792

59 Kiyuna T, Tome Y, Murakami T, Kawaguchi K, Igarashi K, Miyake K, Miyake M, Li Y, Nelson SD, Dry SM, Singh AS, Russell TA, Elliott I, Singh SR, Kanaya F, Eilber FC and Hoffman RM: Trabectedin arrests a doxorubicin-resistant PDGFRA-activated liposarcoma patient-derived orthotopic xenograft (PDOX) nude mouse model. BMC Cancer 18: 840, 2018. PMID: 29737543. DOI: 10.1002/jcb.26792

60 Higuchi T, Kawaguchi K, Miyake K, Oshiro H, Zhang Z, Razmjooei S, Wangsiricharoen S, Igarashi K, Yamamoto N, Hayashi K, Kimura H, Miwa S, Nelson SD, Dry SM, Li Y, Chawla SP, Eilber FC, Singh SR, Tsuchiya H and Hoffman RM: The combination of gemcitabine and nab-paclitaxel as a novel effective treatment strategy for undifferentiated soft-tissue sarcoma in a patient-derived orthotopic xenograft (PDOX) nudemouse model. Biomed Pharmacother 111: 835-840, 2019. PMID: 30616082. DOI: 10.1016/j.biopha.2018.12.110

61 Murakami T, Singh AS, Kiyuna T, Dry SM, Li Y, James AW, Igarashi K, Kawaguchi K, DeLong JC, Zhang Y, Hiroshima Y, Russell T, Eckardt MA, Yanagawa J, Federman N, Matsuyama R, Chishima T, Tanaka K, Bouvet M, Endo I, Eilber FC and Hoffman RM: Effective molecular targeting of CDK4/6 and IGF-1R in a rare FUS-ERG fusion CDKN2A-deletion doxorubicin-resistant Ewing's sarcoma patient-derived orthotopic xenograft (PDOX) nudemouse model. Oncotarget 7: 47556-47564, 2016. PMID: 27286459. DOI: 10.18632/oncotarget.9879

62 Miyake K, Kawaguchi K, Kiyuna T, Miyake M, Igarashi K, Zhang Z, Murakami T, Li Y, Nelson SD, Elliott I, Russell T, Singh A, Hiroshima Y, Momiyama M, Matsuyama R, Chishima T, Endo I, Eilber FC and Hoffman RM: Regorafenib regresses an imatinibresistant recurrent gastrointestinal stromal tumor (GIST) with a mutation in exons 11 and 17 of c-kit in a patient-derived orthotopic xenograft (PDOX) nude mouse model. Cell Cycle 17: 722-727, 2018. PMID: 27286459. DOI: 10.18632/oncotarget.9879

63 Miyake K, Kiyuna T, Kawaguchi K, Higuchi T, Oshiro H, Zhang Z, Wangsiricharoen S, Razmjooei S, Li Y, Nelson SD, Murakami T, Hiroshima Y, Matsuyama R, Bouvet M, Chawla SP, Singh SR, Endo I and Hoffman RM: Regorafenib regressed a doxorubicin-resistant Ewing's sarcoma in a patient-derived orthotopic xenograft (PDOX) nude mouse model. Cancer Chemother Pharmacol 83: 809-815, 2019. PMID: 30758647. DOI: 10.1007/s00280-019-03782-w

64 Hoffman RM: Orthotopic metastatic mouse models for anticancer drug discovery and evaluation: a bridge to the clinic. Invest New Drugs 17(4): 343-359, 1999. PMID: 10759402. DOI: $10.1023 / \mathrm{a}: 1006326203858$

65 Hoffman RM: Patient-derived orthotopic xenografts: better mimic of metastasis than subcutaneous xenografts. Nat Rev Cancer 15(8): 451-452, 2015. PMID: 26422835. DOI: $10.1038 / \mathrm{nrc} 3972$

66 Hoffman RM: Orthotopic is orthodox: why are orthotopic-transplant metastatic models different from all other models? J Cell Biochem 56(1): 1-3, 1993. PMID: 7806583. DOI: 10.1002/jcb.240560102

67 Yang M, Reynoso J, Bouvet M and Hoffman RM: A transgenic red fluorescent protein-expressing nude mouse for color-coded imaging of the tumor microenvironment. J Cell Biochem 106(2): 279-84, 2009. PMID: 19097136. DOI: 10.1002/jcb.21999

68 Igarashi K, Kawaguchi K, Murakami T, Miyake K, Kiyuna T, Miyake M, Hiroshima Y, Higuchi T, Oshiro H, Nelson SD, Dry SM, Li Y, Yamamoto N, Hayashi K, Kimura H, Miwa S, Singh SR, Tsuchiya H and Hoffman RM: Patient-derived orthotopic xenograft models of sarcoma. Cancer Lett 469: 332-339, 2020. PMID:31639427. DOI: 10.1016/j.canlet.2019.10.028

Received March 25, 2020

Revised April 14, 2020

Accepted April 21, 2020 